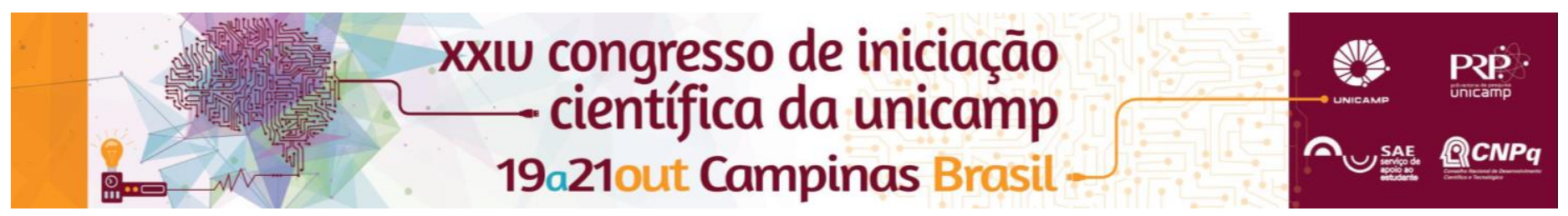

\title{
Superfícies de Cimeira e Perfis de Alteração Associados no Planalto de Franca no Estado de São Paulo.
}

\section{Francisco Sergio Bernardes Ladeira (PQ), Maria Júlia Buck Rossetto (IC).}

\section{Resumo}

O território brasileiro possui uma história geológica, climática e geomorfológica dinâmica. As mudanças climáticas somadas à estabilidade de processos endógenos propiciou o desenvolvimento de extensos perfis lateríticos que naturalmente podem ser correlacionados, devido às localizações, materiais e idade. Perfis lateríticos são caracterizados por volumes que foram submetidos a intenso intemperismo e por conta disso são testemunhas dos processos ativos no momento no decorrer de seu desenvolvimento, sendo fontes importantes sobre as condições paleoclimáticas de determinada área. A partir das informações associadas aos perfis lateíriticos, este trabalho tem como objetivo correlacionar as paleosuperfícies da região de Franca (SP) através de material laterítico em alteração.

\section{Palavras-chave:}

Perfil Laterítico; Paleosuperfície; Ferricrete.

\section{Introdução}

A formação da Terra abarca inúmeros processos que caracterizam momentos geológicos específicos, com características paleoclimáticas distintas; portanto, no decorrer do tempo geológico, a superfície que recobre o planeta é bastante instável. Porém, mesmo com a sensibilidade da superfície às dinâmicas cíclicas que ocorrem de forma contínua, as alterações consequentes destas transformações podem ser gravadas, e através destes registos é possível reconstruir relevos pretéritos.

Com base na análise de perfis lateríticos na região de Franca (Figura 1) e na correlação de paleosuperfícies, este trabalho se propõe a estudar a relação e perfis nesta e em outras áreas de estudo, procurando reconstruir paleosuperfícies. Para atingir este objetivo foram realizadas atividades de campo e escritório. Ressalta-se que este projeto tem como proposta prosseguir com o trabalho associado ao projeto PIBIC "Superfícies de Cimeira e Perfis de Alteração Associados no Nordeste do Estado de São Paulo ".

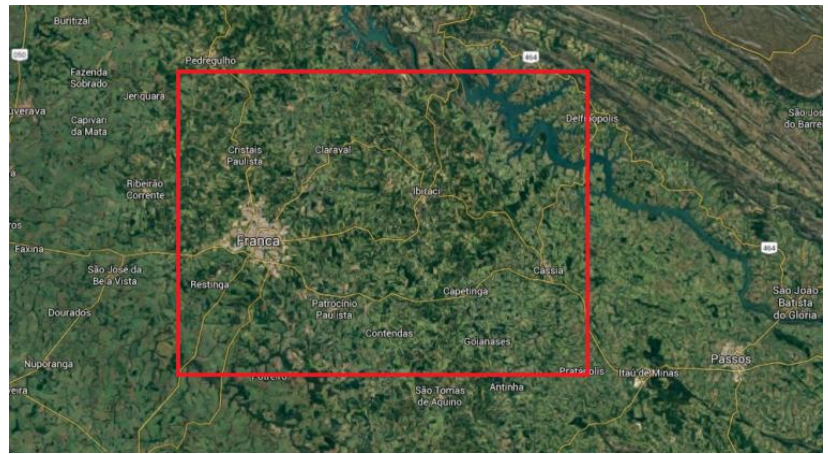

Figura 1. Localização da região projetada para o estudo. Fonte: Google Earth.

\section{Resultados e Discussão}

Com o término das etapas previstas para o projeto, foi possível concluir determinados aspectos sobre a área. Inicialmente, as formações Botucatu e Serra Geral aparecem constantemente associadas à Formação Itaqueri, a qual possui evidências de processos de silificação que revelam outros processos de alteração atuantes na região. Além disso, as ferricretes foram encontradas em altitudes diferenciadas, o que demonstra o transporte de material. A altitude aproximada em que os primeiros depósitos começam a se desenvolver na região é de 960 à $980 \mathrm{~m}$, podendo aparecer em altitudes inferiores por conta de processos gravitacionais que desprendem parte do material (Figura 2).

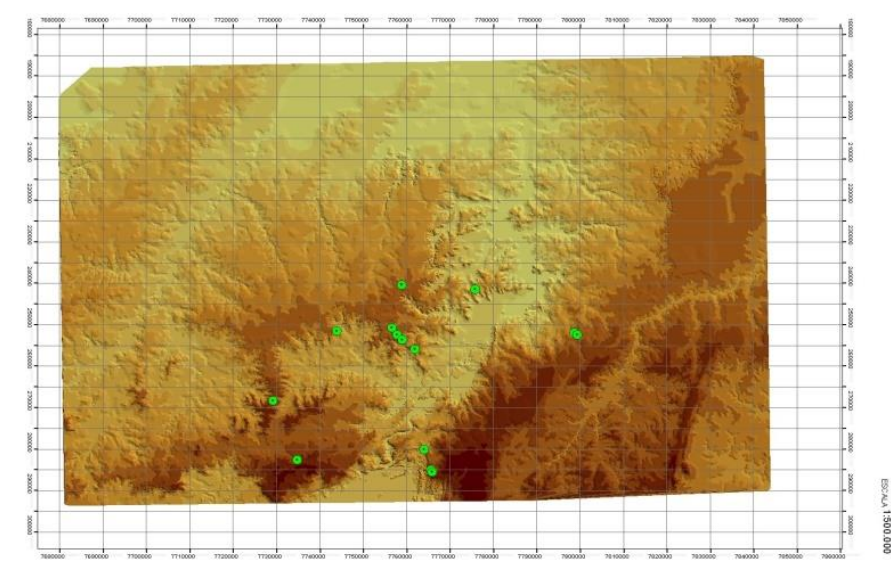

Figura 2. Modelo digital de elevação com alguns dos pontos coletados em campo.Escala 1:50000. Produzido através do ArcMap 10.3. Os pontos representam o trajeto percorrido no campo, no qual foram realizadas coletas e descrições.

\section{Conclusões}

$\mathrm{Na}$ área pesquisada pode concluir que: a) na área ela está associada à ocorrência da Formação Itaqueri e perfis lateríticos de ferro; b) outros processos de alteração como silicificação ocorrem na região; c) ferricretes são encontradas em altitudes diferenciadas, possuindo como cota base uma altimetria entre 960 e $980 \mathrm{~m}$.

\section{Agradecimentos}

Ao Cnpq, que proporcionou o desenvolvimento da pesquisa.

\footnotetext{
${ }^{2}$ MCFARLANE, M.J. Laterite and Landscape: [1976]. 151pp.
} 